\title{
TTR
}

Traduction, terminologie, re?daction

\section{Multiple Meanings and Contexts: the Diversity of the Post-Colonial}

\section{Paul St-Pierre}

Volume 10, numéro 1, 1er semestre 1997

Langues, traduction et post-colonialisme

Languages, Translation and Post-Colonialism

URI : https://id.erudit.org/iderudit/037278ar

DOI : https://doi.org/10.7202/037278ar

Aller au sommaire du numéro

Éditeur(s)

Association canadienne de traductologie

ISSN

0835-8443 (imprimé)

1708-2188 (numérique)

Découvrir la revue

Citer cet article

St-Pierre, P. (1997). Multiple Meanings and Contexts: the Diversity of the

Post-Colonial. TTR, 10(1), 9-17. https://doi.org/10.7202/037278ar d'utilisation que vous pouvez consulter en ligne.

https://apropos.erudit.org/fr/usagers/politique-dutilisation/ 


\section{Multiple Meanings and Contexts : the Diversity of the Post-Colonial}

In the introduction to Imperial Eyes : Travel Writing and Transculturation Mary Louise Pratt describes growing up in the small Ontario town of Listowel, with its drugstore run by Dr. Livingstone, "a grand nephew of the 'real' Dr. Livingstone in Africa". And she remarks, "English Canada was still colonial in the $1950 \mathrm{~s}$ : reality and history were somewhere else, embodied in British men"'. Pratt's use of 'colonial' here could be questioned; after all, Canada had become a nation in 1867, with the passing, in the British Parliament, of the British North America Act, and had gained further independence in 1931 through the Statute of Westminster, also enacted by the Parliament of the United Kingdom, which gave legislatures in Canada the right to pass any laws they should wish to, with extra-territorial effect. The Statute stipulated that "[i]n future neither the Dominion nor any province thereof shall be described as a 'colony' in any Act of the parliament of the United Kingdom" ${ }^{\text {"2 }}$. The very existence of these two dates, however, 1867 and 1931 - to which could be added a third, that of the repatriation of the Canadian Constitution in 1982 - makes it impossible to consider 1867 as marking the end of the colonial era in Canada. If political independence from the imperial power is difficult to pinpoint in Canadian history, the end of colonial hegemony is even more difficult, and Pratt's characterization of English Canada in the early 1950 s seems particularly apt. Indeed, my own memories of growing up in a small town in Quebec are hardly different, marked by the

celebration in 1952 of the British Queen's coronation, the yearly parades by the veterans who had fought in World War II to defend the colonial

I Mary Louise Pratt, Imperial Eyes : Travel Writing and Transculturation, London, Routledge, 1992, p. 1.

${ }^{2}$ The Encyclopedia of Canada, ed. W. Stewart Wallace, volume IV, Toronto, University Association of Canada, 1948, p. 30. 
powers $^{3}$, the references in the local newspapers to the meetings of the Imperial Order of the Daughters of the Empire, and the various signs and symbols of Empire punctuating daily life, from the images of the Queen and her consort looking down from classroom walls to the British flag floating over public buildings. The overlap here of the colonial and the post-colonial points to one of the difficulties in the use of the term 'post(-)colonialism'. Graham Pechey notes this overlap in the case of South Africa :

'Postcolonial' has a banal sense which might apply equally to South Africa after 1910 and India after 1947 : the sense of formal political 'independence', of having gone through a transfer of power, or of belonging to the period after the transfer. The reality of course is that 'postcolonial' is only too often a polite expression for states that are both economically and culturally neocolonial. Indeed - if we except the early one-off case of Liberia - South Africa might be called the first neocolonial state in Africa. It all depends on where you stand, where you are looking from, what you choose to look at. That this statist or centralist meaning of 'postcolonial' is a weak sense of the term is clear when one reflects that from the standpoint of most of its citizens South Africa is anything but postcolonial, plunged as they were after 1948 into that worst of all forms of colonial subordination : the plight of finding themselves forcibly written into somebody else's narrative of redemption-after-long-persecution; in the condition (just when it seemed they would enjoy the fruits of the victors) of being what Edward Said has called, with reference to the Palestinians, the 'victims of victims'. The stronger sense of 'postcolonial' emerges when we consider this seeming paradox : that it takes anticolonial struggles to produce neocolonial conditions. The postcolonial condition is the perspective one enters when one has resolved that paradox, relished that irony of history, and moved on. Postcoloniality in this sense is not confined to any particular kind of geopolitical space : it applies equally to the experience of diasporic and autochthonous communities, settler colonies no less than to territories of indirect rule, South African apartheid no less than to Indian democracy. Resisting any simple periodising

${ }^{3} \mathrm{My}$ phrasing here wishes to draw attention both to the divisions within Canadian society around the question of conscription and to the possibility of a different significance being given this conflict when viewed from a (post)colonial perspective. 
correlations, the postcolonial condition is not one of power secured and centrally exercised in certain times and places. It is rather a dispersal, a moving field of possibilities which everywhere carry within them the mutually entailing, intimately cohabiting negative and positive charges of both power and resistance. ${ }^{4}$

Not only then can there not be any clear and absolute distinction between colonial and postcolonial, but this binary pairing needs to be broken apart and each term situated in relation to others, among which are those used here by Pechey : neocolonial ${ }^{3}$, the postcolonial condition, and postcoloniality ${ }^{6}$. Still other distinctions would have to be made. Between 'post-colonial' with a hyphen, and 'postcolonial' without, for example. In their "Introduction" to Colonial Discourse/Postcolonial Theory Barker, Hulme and Iversen use the first "as a temporal marker" and the second "to indicate the analytical concept of greater range and ambition, as in 'postcolonial theory'[... $]^{n 7}$. Which brings us back to Pratt's description of Ontario in the 1950s, for despite being post-colonial, Canada was not at the time postcolonial; nor does being postcolonial necessarily even depend upon being post-colonial. Stephen Slemon points out that 'post-colonial" "locates a specifically anti- or post-colonial discursive purchase in culture, one which begins in the moment that colonial power

"Graham Pechey, "Post-apartheid Narratives" in Colonial Discourse/Postcolonial Theory, ed. Francis Barker, Peter Hulme, and Margaret Iversen, Manchester, Manchester University Press, 1994, pp. 152-53.

${ }^{5}$ Neo-colonialism has been used in more than one sense and context to describe the continued Hegemonic influence of colonial powers after Independence through the application of economic, cultural, and political pressures. However, the term is also widely used to denote the replication of colonial authorities and institutions in the rule and administration of independent, self-governing countries", in Peter Childs and Patrick Williams, An Introduction to Post-Colonial Theory, London, Prentice-Hall, 1997, pp. 231-32.

${ }^{6}$ Consider the following remark by Gayatri Spivak in Childs and Williams, p. 16 : "Neo-colonialism is not simply the continuation of colonialism; it is a different thing. That is what I call 'postcoloniality', and I find the word postcolonialism just totally bogus".

7 "Introduction", Colonial Discourse/Postcolonial Theory, p. 4. 
inscribes itself onto the body and space of its Others and which continues as an often occulted tradition into the modern theatre of neo-colonialist international relations. A post-colonial critical discourse is therefore never wholly absent from colonial culture : there is always at work in the discourses of the colonised a network of disidentificatory traditions ${ }^{\text {48 }}$. In yet another complication of the term it needs to be remarked as well that it is not only the colonies of the imperial powers which, once independent, become post-colonial; the imperial power too passes into another, also post-colonial, mode. If Great Britain is now in some sense a post-colonial nation it is precisely because (most of) its colonies are now independent and that the end of colonial power has produced substantial changes within British society itself 9 . However, if the former imperial powers are now 'post-colonial', they are post-colonial in a very different sense than their former colonies are, and it is vital that this difference between the histories of the two be maintained and emphasized. Indeed, one of the main dangers in the use of a term such as 'postcolonialism' is the risk of conflating different historical positions and situations to the ahistorical and undifferentiated repetition of a single structure. Anne McClintock discusses these not purely terminological problems in "The Angel of Progress : Pitfalls of the Term Postcolonialism"'10. Among the arguments she raises against 'postcolonialism' are the following four (pp. 85-86) : 1) the notion of linear development and of 'progress' inherent in the term : "Metaphorically, the term 'post-colonialism' marks history as a series of stages along an epochal road from 'the precolonial' to 'the colonial' to 'the

'Stephen Slemon, "Modernism's Last Post", in Ian Adam and Helen Tiffin, ed., Past the Last Post. Theorizing Post-colonialism and Post-modernism, Calgary, University of Calgary Press, 1990, p. 3.

9 These changes in post-colonial Britain have been pointed out by Ruth Frankenberg and Lata Mani : "BRITAIN : 'postcolonial' signals loss of most, though not all, former colonies - bear in mind Hong Kong, N. Ireland, the appearance on British landscapes of a significant number of people from the former colonies : 'we are here because you were there'. The transition from a society of predominantly white ethnic groups to one that is multiracial. The 'other' no longer geographically distanced, but within, and over time significantly shaping landscape and culture. Samosas at the National Theatre café. Race Riots". quoted in Childs and Williams, p. 78).

${ }^{10}$ Social Text, 31/32, n.d., pp. 84-98. 
post-colonial $^{\text {m }}$; 2) the lack of distinction between "the beneficiaries of colonialism (the ex-colonizers) and the casualties of colonialism (the ex-colonized)"; 3) the implicit Eurocentrism of the term : "The term confers on colonialism the prestige of history proper; colonialism is the determining marker of history. Other cultures share only a chronological, prepositional relation to a Eurocentred epoch that is over (post-), or not yet begun (pre-). In other words, the world's multitudinous cultures are marked not positively by what distinguishes them but by a subordinate, retrospective relation to linear, European time"; and 4) the reduction of multiplicity to singularity: "The term [postcolonialism] also signals a reluctance to surrender the privilege of seeing the world in terms of a singular and ahistorical abstraction. [...] The following proliferate : 'the post-colonial condition', 'the post-colonial scene', 'the post-colonial intellectual' [...]".

McClintock also points out that colonization itself has taken many forms : internal colonization, for instance, "where the dominant part of a country treats a group or region as it might a foreign colony", needs to be distinguished from imperial colonization, "large-scale, territorial domination of the kind that gave late Victorian Britain and the European 'lords of humankind' control over $85 \%$ of the earth [...]" (p. 88). The three papers relating to Canada in this issue underline the different complexities involved in postcolonial contexts in particular in settler colonies ${ }^{11}$. The presence of native peoples underscores the fact that whatever the relations of the former colonists to the imperial power(s) or between themselves, the colonial ethos continues in their relations to those nations which first inhabited the land and which were subsequently displaced. Using both 17th-century and 20th-century examples, Barbara Godard describes the attempt to marginalize and subdue Amerindians, as well as resistance to such attempts through the reinvention of their relations to their colonizers. Marc Charron, on the other hand, examines retranslations of a notorious 19th-century British report (Lord Durham's Report) recommending the assimilation of the French settlers by the English, and finds in these translations the changing dynamics characterizing the relations between

11 Such colonies are "distinguished by their formal independence from the founding metropolitan country, along with continued control over the appropriated colony (thus displacing colonial control from the metropolis to the colony itself)" (McClintock, p. 89). 
the two settler groups. Finally, Jane Dunnett points to the identification by 20th-century Québécois writers and intellectuals with the position of the colonized in relation to the cultural domination of France, the political and economic power of English Canada, and the hegemony of Roman Catholic religious authorities within Québec itself. These three separate ways of figuring the Canadian situation are quite different, and their differences are telling : they indicate the impossibility, in fact, of reducing four hundred years of history to a neat, binary opposition between the colonial and the post(-)colonial, all the more so since, precisely, at least three communities are involved. The attempt to exclude one of these, the Amerindians, is precisely one of the legacies of colonial rule, an example of intemal colonization, where each of the settler communities must be seen as treating "a group or region as it might a foreign colony"; the attempt on the part of the British to assimilate another of these communities, the French, corresponds to another-imperial-form of colonization $^{12}$. In addition to the various forms colonization has taken, decolonization has been more or less complete as well; in certain cases, such as the break-away settler colonies, there has been no decolonization at all. These various 'pitfalls' make it clear that 'post-colonialism' and its derivatives need always to be used in a way which admits of local and regional specificity, and which shifts the focus from the colonizer to the effects of colonization on its victims.

${ }^{12}$ Linda Hutcheon writes of the Canadian context viewed from a post-colonial perspective : "In Canada, it has been Québécois artists and critics who have embraced most readily the rhetoric of [...] post-colonial liberation - from Émile Borduas in 1948 to Parti Pris in the 1960s. However real this experience of colonization is in Québec, there is a historical dimension here that cannot be ignored. Québec may align itself politically with francophone colonies such as Algeria, Tunisia and Haiti [...], but there is a major political and historical difference : the pre-colonial history of the French in Quebec was an imperialist one. As both Leonard Cohen's Beautiful Losers and Hubert Aquin's Trou de mémoire point out, the French were the first imperial force in what is now Canada and that too cannot be forgotten - without risking bad faith. This is not to deny, once again, the very real sense of cultural dispossession and social alienation in Québec, but history cannot be conveniently ignored". In "Circling the Downspout of Empire", Adam and Tiffin, p. 170. 
It could be asked whether it is even possible to use 'postcolonial' in this way. Childs and Williams argue that it is. In the conclusion to their Introduction to Post-Colonial Theory they opt for the continued use of the term precisely because of the emphasis it places on the centrality of colonialism for much of the world's population, while at the same time underscoring resistance and reaction:

It can therefore be argued that in post-colonialism's insistence on the displacement and repudiation of a pervasive colonial ideology, the centrality of colonialist perspectives, and of colonialism as the pivotal historical event for scores of diverse countries, is confirmed not replaced. The label post-colonialism therefore, if preserved, needs not to be thought of as defining a doctrine, like colonialism, but as marking a strategic phase. Post-colonial is a term which, like 'post-fascist-Europe', both draws attention to a none-too-distant iniquitous past and affirms a commitment to rejecting, not forgetting, the effects and ideologies of that past. ( $p$. 218)

The authors link the concerns of post-colonial theory to the preoccupations of modern theoretical discourse in general :

As communities become more culturally diverse and globally aware, the issues and concerns that affect disparate peoples, in dissimilar and conflicting ways, will more obviously converge and may be described as post-colonial. Those concerns are shaped by hierarchies of power and formed through discourses that contain colonialism within their discursive genealogy. Post-colonial cultures are characterized by a decentring movement, a subversion of universals and unities, and a diversity and hybridity that permeate their past and condition their present. (p. 218)

The diversity and hybridity referred to here are theorized by Mary Louise Pratt as the 'contact zone', a concept she uses "to refer to the space of colonial encounters, the space in which peoples geographically and historically separated come into contact with each other and establish ongoing relations, usually involving conditions of coercion, radical inequality, and intractable conflict" ${ }^{13}$. Borrowing from linguistics, "where

\footnotetext{
${ }^{13}$ Pratt, op.cit, p. 6.
} 
the term contact language refers to improvised languages that develop among speakers of different native languages who need to communicate with each other consistently $[. . .]^{n 14}$, Pratt insists on the way in which the contact zone, by bringing together the colonizer and the colonized, leads to each defining her/himself in relation to the other. In other words, the experiences of colonialism and of decolonization are not simply unidirectional, with power and agency only on one side of the equation. The colonized are not simply passive in colonial situations; rather, as Vicente Rafael has shown in the case of the use of translation in The Philippines, selection and appropriation can be used as strategies of resistance to the attempt to control and dominate ${ }^{15}$. Pratt notes : "A 'contact' perspective emphasizes how subjects are constituted in and by their relations to each other. It treats the relations among colonizers and colonized, or travelers and 'travelees', not in terms of separateness or apartheid, but in terms of copresence, interaction, interlocking understandings and practices, often within radically asymmetrical relations of power" ${ }^{\mathrm{nt}}$.

Another way of speaking of the diversity and hybridity of postcolonial cultures would be to consider them as zones of linguistic and cultural translation. In a review of Bernard S. Cohn's Colonialism and Its Forms of Knowledge. The British in India ${ }^{17}$, Homi Bhabha emphasizes the way in which such translation - a direct result of the colonial experience - questions prior categories of meaning and experience :

His [Cohn's] interest, and the attention of many revisionist historians, is focused on a process that may be described as the misrule of cultural translation : the very act of moving between

${ }^{14}$ Ibid., p. 6.

15 Vicente L. Rafael, Contracting Colonialism. Translation and Christian Conversion in Tagalog Society Under Spanish Rule, Durham, Duke University Press, 1993.

${ }^{16}$ Pratt, op.cit., p. 7.

${ }^{17}$ Princeton, Princeton University Press, 1996. 
linguistic systems of cultural traditions introduces an element of contingency or indeterminacy in implementation, that does not have a prior existence within the discrete world of any singular culture or language. Cultural translation is not simply appropriation or adaptation; it is a process through which cultures are required to revise their own systems of reference, norms and values, by departing from their habitual or 'inbred' rules of transformation. Ambivalence and antagonism accompany any act of cultural translation, because negotiating with the 'difference of the other' reveals the radical insufficiency of our own systems of meaning and signification $[\ldots]^{18}$

Contingency and indeterminacy are the keywords here, whether they are rewritten as diversity and hybridity, or as ambivalence and antagonism. And they are to be found more specifically on the linguistic level as well. Indeed, most of the articles published in this issue problematize the practice of translation in postcolonial settings, whether by emphasizing the way in which the interaction between languages resulting from colonialism (vernacularization, creolization, or perceptions relating to the 'values' of languages in multilingual settings) breaks down what are usually thought of as discrete self-contained entities, or by rewriting texts in other languages, reversing, but at times also reinventing, the colonial relations of power. What these articles show is that indeed the appropriation attempted, or resisted, through translation is never entirely successful, that the very fact of translation - when recognized, and the recognition of the fact of translation is vitally important - refers/defers the reader to another, a different space.

Paul St-Pierre

Département de linguistique et de traduction

Université de Montréal

${ }^{18}$ Times Literary Supplement, 8 August 1997, p. 14. 